\begin{tabular}{|c|c|c|c|}
\hline Diterima: 5 Mei 2021 & Direvisi: 4 Juli 2021 & Disetujui: 10 Juli 2021 & Dipubikasi: 13 Juli 2021 \\
\hline
\end{tabular}

\title{
ANALISIS KINERJA ANGGARAN PEMERINTAH PROVINSI SUMATERA SELATAN DENGAN KONSEP VALUE FOR MONEY
}

\author{
Periansya $^{1}$, M. Dandy Pratama ${ }^{2}$, Rosy Armaini' ${ }^{3}$, Sopiyan A.R ${ }^{4}$ \\ ${ }^{1-4}$ Jurusan Akuntansi, Politeknik Negeri Sriwijaya \\ Email: periansya@polsri.ac.id
}

\begin{abstract}
Abstrak
Penelitian ini dimaksudkan sebagai upaya untuk menganalisis Organisasi Perangkat Daerah di Provinsi Sumatera Selatan yang ditinjau dari kinerja anggaran melalui konsep value for money. Penelitian ini melibatkan variabel dependen kinerja anggaran organisasi perangkat daerah dan variabel independen mencakup transparansi, akuntabilitas, dan pengawasan. Data primer yang berasal dari kegiatan menginput kuesioner ditujukan kepada responden yang dipilih pada 21 Organisasi Perangkat Daerah (OPD) dengan pendekatan purposive sampling yang dianalisa melalui analisis regresi linear berganda. Hasil atas analisis dan pembahasan pengujian hipotesis menjelaskan jika secara langusng transaparansi, akuntabilitas, dan pengawasan memiliki keterkaitan yang positif dan signifikan terhadap kinerja anggaran OPD, disamping itu secara bersamaan menjelaskan adanya pengaruh yang positif dan signifikan sebesar $44,6 \%$ terhadap kinerja anggaran dan sisanya sebesar $55,4 \%$ dijelaskan oleh variabel lain diluar dari penelitian ini. Kesimpulan dari penelitian ini menyatakan bahwa kinerja anggaran melalui konsep value for money membutuhkan keterlibatan transparansi, akuntabilitas dan pengawasan, selain itu variabel pengawasan perlu dilakukan perhatian lebih guna tercapainya kinerja anggaran yang baik disamping variabel lain yang perlu diteliti seperti ketaatan hukum dan partisipasi masyarakat.
\end{abstract}

Kata kunci: Transparansi, Akuntabilitas, Pengawasan, dan Value for Money.

\section{ANALYSIS PERFORMANCE SOUTH SUMATRA PROVINCIAL GOVERNMENT BUDGET WITH CONCEPT OF VALUE FOR MONEY}

\begin{abstract}
This research is intended to analyze the Organization of Devices in South Sumatra Province in terms of the performance of the value for money concept. This research involves the dependent variable is regional apparatus budget performance, the independent variable contains transparency, transparency, accountability, and supervision. The data used is primary obtained from the results of the distribution of questionnaires addressed to respondents selected in 21 Regional Apparatus Organizations (OPD) using a purposive sampling approach which was analyzed through multiple linear regression analysis. The results of the analysis and bypothesis testing explain simultaneously, accountability, and supervision have a positive and significant relationship to the OPD budget, in addition to simultaneously explaining the existence of a positive and significant influence of $44.6 \%$ on-budget performance, and the remaining $55.4 \%$ explained by other variables outside of this study. The conclusion of this study states that the budget through the value-for-money concept approach requires maximum transparency, accountability, and supervision, besides that the monitoring variable that needs to be done is the achievement of a good budget in addition to other variables that need to be considered such as legal compliance and community participation.
\end{abstract}

Keywords: transparency, accountability, supervision, and V alue for Money. 
I-FINANCE: a Research Journal on Islamic Finance Vol.07 No. 01 Juni 2021 http//jurnal.radenfatah.ac.id/index.php/i-finance

Periansya, M. Dandy P, Rosy Armaini dan Sopiyan ............Analisis Kinerja Anggaran

\section{PENDAHULUAN}

Pasca reformasi Indonesia mendorong beralihnya sistem penganggaran sejak dikeluarkannya Undang-Undang Nomor 17 Tahun 2003, didukung oleh Undang-Undang Nomor 33 Tahun 2004 tentang perimbangan keuangan, dan Undang-Undang Nomor 32 Tahun 2004 tentang otonomi daerah. Berbagai perubahan diperlukan untuk dapat memenuhi tuntutan masyarakat yang dimaksudkan agar adanya progres kinerja pemerintah pada bidang pemerataan pembangunan, terlaksananya standar pelayanan publik di berbagai daerah dan pemanfaatan pengelolaan sumber daya yang ada. Anggaran memiliki peran sebagai alat monitoring kegiatan pemerintahan, dan perencanaan pelaksanaan kegiatan pelayanan publik yang diukur melalui satuan mata uang sekaligus juga sebagai pengendalian terlaksananya kegiatan publik. Kebutuhan rincian pengalokasian penggunaan anggaran melibatkan panitia penyusun anggaran dalam mempertimbangkan target dan sasaran yang akan dicapai oleh instansi di pemerintahan (Laksana \& Handayani, 2014).

Sistem penganggaran yang memiliki pola tradisional sudah tidak tepat lagi diterapkan mengingat perkembangan zaman yang terus mengalami perubahan, diperlukannya sistem anggaran yang mampu memenuhi kebutuhan masyarakat di era saat ini dengan basis kinerja anggaran. Penganggaran melalui anggaran kinerja sangat memperhatikan aspek efisiensi anggaran atas pelaksanaan kegiatan. Efisien merupakan komparasi antara output dan input (Mardiasmo, 2019) yang berarti aktivitas pelaksanaan program dan kegiatan yang menggunakan anggaran secara efisien, ketika kontribusi atas keluaran yang diperoleh memiliki kesetaraan dengan masukan yang kurang dari sama dengan keluaran. Efektif, efisien dan ekonomis merupakan elemen utama prinsip $V$ alue For Money dalam pengelolaan anggaran pemerintah (Purwiyanti, 2017). Kriteria yang dimiliki oleh anggaran yang dikategorikan baik ketika anggaran mampu menggambarkan konsep dari $V$ alue for Money (Purwiyanti, 2017). Meningkatnya anggaran kinerja di sektor publik diindikasikan karena adanya implementasi konsep dari Value for Money, yang mana ketika suatu organisasi mampu mengelola dengan baik atas biaya masukkan seminimal mungkin untuk memperoleh keluaran yang maksimal perihal tindakan preventif dan kuratif mencapai suatu tujuan yang ditargetkan (Khalikussabir, 2017) dan (Mardiasmo, 2009). Keterlibatan akuntabilitas dan transparansi pada proses penganggaran di Indonesia memiliki peranan pada tercapainya pemerintahan yang baik yang dikenal dengan good governance. Peningkatan akuntabilitas publik dilakukan melalui terukurnya kinerja anggaran instansi pemerintah sesuai dengan tolak ukur yang ditetapkan (Laoli, 2019). Selain akuntabilitas, transparansi, dan pengawasan terkait perencanaan penganggaran berjalan dengan baik melalui konsep efisien, efektif, dan ekonomis (Purnomo \& Putri, 2018). Kriteria anggaran dapat dikatakan berjalan dengan baik apabila penggunaan anggaran mempunyai peranan pada progres suksesnya organisasi/instansi terkait dengan tercapainya aspek kesejahteraan. Melalui konsep Value for Money memiliki potensi pada meningkatnya kinerja anggaran di sektor publik.

Hasil audit atas Laporan Keuangan Pemerintah Daerah di wilayah Sumatera Selatan yang dilakukan oleh Badan Pemeriksa Keuangan (BPK) dengan opini Wajar Tanpa Pengecualian diperoleh beberapa hasil temuan yakni mencakum sangat krusialnya pelaksanaan kegiatan mengelola aset pemerintah tahun anggaran 2018 dan 2019 pada tri semester pertama karena 11 temuan terkait dengan penyimpangan terhadap aktivitas administrasi dan 12 permasalahan yang berkaitan dengan ketidaksesuaian terhadap regulasi peraturan perundang-undangan seperti adanya lebih bayar yang mencapai Rp80,72 juta, hal ini terjadi karena wilayah Provinsi Sumatera Selatan masih belum tertib misalnya dalam hal 
hibah aset tetap berupa alat pertanian di Kementerian Pertanian tidak dilakukannya proses pencatatan pada rekap klasifikasi aset tetap dan upaya tindakan preventif atas aset tetap tanah belum begitu maksimal dilakukan. Sesuai dengan uraian diatas terkait dengan hasil audit oleh BPK, peneliti tertarik untuk melakukan penelitian atas penggunaan konsep apa saja yang mampu meningkatkan hasil akhir kinerja anggaran Pemerintah Provinsi Sumatera Selatan. Kegiatan meneliti yang telah dilakukan oleh (Laoli, 2019) dan (Candrakusuma \& Jatmiko, 2017) yang menyatakan bahwa transparansi tidak berpengaruh positif dan tidak signifikan pada kinerja anggaran yang berkonsep V alue for Money. Hal ini bertolak belakang dengan penelitian oleh (Wijayanti \& Babulu, 2019) menunjukkan hasil transparansi publik berpengaruh positif terhadap kinerja anggaran.

Menurut (Sofyani,2016) Anggaran Kinerja berdasarkan Peraturan Pemerintah 105/2000 menyatakan bahwa Pemerintah Daerah diharuskan untuk menyusun APBD dengan basis anggaran kinerja, standar kinerja, standar biaya dan benchmark atas pemberian pelayanan publik. Penyusunan anggaran mempertimbangkan program dan kegiatan yang akan dilaksankan pada tahun anggaran bersangkutan diukur dengan biaya satuan agar dapat mencapai standar pelayanan publik. Setiap Organisasi Perangkat Daerah (OPD) menyusun anggaran yang akan digunakan untuk melaksanakan tugas dan fungsinya diukur melalui indikator program dan kegiatan yang akan dilaksanakan dan harus bisa dipertanggungjawabkan penggunaannya. Dengan pendekatan ini, setiap jenis pelayanan publik yang diberikan akan dapat diukur dengan satuan biaya agar dapat terlaksananya prinsip efisien dan efektifitas penggunaan anggaran untuk setiap pelayanan publik yang diberikan. Anggaran kinerja mendorong terjalinnya keterkaitan antara input, output dan outcome yang dapat membuat sistem pemerintahan yang baik. Pendekatan kinerja dapat menunjukkan aspek tanggung jawab (accountability) dan keterbukaan (transparency) perihal implementasi pelayanan publik kepada masyarakat. Sehingga melalui anggaran kinerja, kuantitas anggaran yang tersedia (input) untuk per Organisasi Perangkat Daerah akan sebanding dengan kuantitas pemberian pelayanan publik untuk kepentingan masyarakat (output).

Menurut (Reynowijoyo,2013) Transparansi merupakan salah satu prinsip good corporate governance. Transparansi dibangun melalui konsep kemudahan mengakses informasi resmi yang akurat terkait dengan kegiatan pemerintahan dan lembaga-lembaga yang dapat dengan mudah diperoleh informasinya oleh pihak yang mempunyai kepentingan sebagai upaya monitoring yang dilakukan.

Menurut (Indira,2010) Akuntabilitas merupakan suatu aksi pertanggungjawaban mengenai kegiatan atas pengambilan keputusan dan atau tindakan oleh para pemimpin pengelola organisasi sektor publik kepada pihak yang mempunyai kepentingan (stakeholder) serta masyarakat. Dilihat dari lingkup organisasi pemerintahan misalnya, akuntabilitas merupakan pertanggungjawaban atas tindakan dan keputusan pihak pelaksana (eksekutif) kepada perwakilan rakyat (legislatif) serta masyarakat secara umum.

Menurut (Mahmudi,2015) mendefinisikan Value for Money merupakan "Konsep penting dalam organisasi sektor publik yang memiliki pengertian penghargaan terhadap nilai uang. Pengukuran kinerja $V$ alue for Money adalah pengukuran kinerja untuk mengukur ekonomi, efisiensi, dan efektifitas suatu kegiatan, program, dan organisasi.“

Berdasarkan permasalahan yang telah dijabarkan diatas, kegiatan meneliti ini bertujuan untuk membahas dan melanjutkan penelitian yang pernah dilakukan perihal kinerja anggaran berkonsep V alue for Money pada Pemerintah Daerah di wilayah Provinsi Sumatera Selatan apakah mempunya hubungan keterkaitan secara positif yang signifikan 
secara bersamaan ataupun tersendiri antar variabel, yang mana hasil penelitian ini nantinya diharapkan agar dapat memberikan insight baru untuk pemerintah atas kegiatan mempertimbangkan hasil akhir dari suatu kebijakan dan juga sebagai tambahan masukkan untuk peneliti selanjutnya.

\section{METODE PENELITIAN}

\section{Variabel Penelitian}

Variabel penelitian ini melibatkan variabel Independen (X) yang dikenal dengan variabel stimulus, predictor, antecedent atau variabel yang mempengaruhi (Sugiono, 2012) yang terdiri dari 4 variabel independen yaitu Transparansi $\left(\mathrm{X}_{1}\right)$ yang terdiri dari dimensi komunikasi pubik oleh pemerintahan dan hak masyarakat terhadap akses informasi, Akuntabilitas $\left(\mathrm{X}_{2}\right)$ terdiri dari beberapa dimensi yakni kejujuran, hukum, proses, program, kebijakan, dan finansial, dan Pengawasan Pengawasan $\left(\mathrm{X}_{3}\right)$ terdiri dari dimensi penyusunan, pengawasan, penilaian, peran yang berwenang dan revisi. Sedangkan variabel Dependen $(\mathrm{Y})$ atau variabel terikat dalam penelitian ini yaitu Kinerja Anggaran dengan dimensi ekonomis, efektif dan efesien.

\section{Populasi dan Sampel}

Populasi pada penelitian ini merupakan Organisasi Perangkat Daerah Provinsi Sumatera Selatan. (Sugiono,2012) mengungkapkan bahwa Populasi adalah cakupan luasnya secara keseluruhan mengenai objek dan subjek dengan mempertimbangkan kualitas dan karakteristik yang ditetapkan yang selanjutnya diimplementasikan oleh peneliti untuk menelaah dan menarik intisari secara keseluruhannya. Sampel pada penelitian ini adalah Badan, Dinas, dan Inspektorat Pemerintah Provinsi Sumatera Selatan. Sampel yang diambil dalam penelitian ini adalah 5 orang dari 21 OPD di Provinsi Sumatera Selatan yang terdiri atas Pengguna Anggaran, Kuasa Pengguna Anggaran, Pejabat Penatausahaan Keuangan, Bendahara Penerimaan dan Bendahara Pengeluaran. Teknik pengambilan sampel dalam penelitian ini menggunakan Purposive sampling.

\section{Teknik Analisis Data}

Pengujian data yang digunakan penelitian ini adalah menggunakan pendekatan pengujian hipotesis mencakup analisis regresi linear berganda, uji koefisien determinasi, uji $\mathrm{T}$, dan uji $\mathrm{F}$.

\section{HASIL PENELITIAN DAN PEMBAHASAN}

\section{Hasil Penelitian}

Tabel 1

Berdasarkan pengolahan data diperoleh hasil sebagaimana yang terlihat pada tabel 1 .

\section{Hasil Analisis Regresi Linear Berganda}

\begin{tabular}{lrrrrrr}
\hline & \multicolumn{2}{c}{ Unstandardized Coefficients } & \multicolumn{2}{c}{$\begin{array}{c}\text { Standardized } \\
\text { Coefficients }\end{array}$} & & \\
\cline { 2 - 4 } & Model & \multicolumn{1}{c}{ B } & Std. Error & Beta & & \multicolumn{1}{c}{ Sig. } \\
\hline (Constant) & 10,821 & 3,424 & & & 3,160 &, 002 \\
\hline Transparansi & 0,261 &, 089 &, 259 & & 2,922 &, 004 \\
\hline Akuntabilitas & 0,267 &, 100 &, 301 & & 2,680 &, 009 \\
\hline Pengawasan & 0,247 &, 102 &, 275 & & 2,419 &, 018 \\
\hline
\end{tabular}

a. Dependent Variable: Kinerja Anggaran

Sumber: Output SPSS IBM, data di olah (2021) 
Berdasarkan Tabel 1 diatas, diketahui jika terdapat pengaruh antara variabel Transparansi, Akuntabilitas, dan Pengawasan terhadap Kinerja Anggaran yang berkonsep Value for Money di OPD Provinsi Sumatera Selatan yang ditunjukkan pada persamaan regresi linear berganda dibawah ini:

$$
\mathrm{Y}=10,821+0,261 \mathrm{X}_{1}+0,267 \mathrm{X}_{2}+0,247 \mathrm{X}_{3}+\mathrm{e}
$$

Dari persamaan tersebut dapat dijelaskan sebagai berikut:

1. Nilai konstanta (a) pada persamaan di atas bernilai positif sebesar 10,821 yang menjelaskan bahwa dengan mengesampingkan pengaruh besarnya pemahaman Transparansi, Akuntabilitas dan Pengawasan maka besarnya Kinerja Anggaran berkonsep $V$ alue for Money adalah positif sebesar 10,821 satuan.

2. Koefisien regresi variabel Transparansi senilai 0,261 . Hal ini menjelaskan bahwa setiap terjadinya perubahan kenaikkan pada variabel Transparansi sebesar satu (1) satuan maka besaran nilai Kinerja Anggaran berkonsep $V$ alue For Money akan berbanding lurus mengikuti besaran kenaikkan senilai 0,261 dengan catatan variabel independen lain bemilai konstan.

3. Koefisien regresi variabel Akuntabilitas senilai 0,267. Hal ini menjelaskan bahwa setiap terjadinya perubahan kenaikkan pada Akuntabilitas sebesar satu (1) satuan maka besaran nilai Kinerja Anggaran berkonsep Value for Money akan berbanding lurus mengikuti besaran kenaikkan senilai 0,267 dengan catatan variabel independen lain bernilai konstan.

4. Koefisien regresi variabel Pengawasan senilai 0,247 . Hal ini menjelaskan bahwa setiap terjadinya perubahan kenaikkan pada Pengawasan sebesar satu (1) satuan maka besaran nilai Kinerja Anggaran berkonsep Value for Money akan berbanding lurus mengikuti besaran kenaikkan senilai 0,247 dengan catatan variabel independen lain bernilai konstan..

Berdasarkan Tabel 1 dapat dijelaskan bahwa hasil Uji Parsial (Uji t) dapat diuraikan sebagai berikut:

1. Pengaruh Transparansi Terhadap Kinerja Anggaran

Besaran nilai thitung Transparansi senilai 2,922 dan nilai ttabel senilai 1,986 diperoleh bahwa nilai thitung $>$ ttabel yang menjelaskan diterimanya hipotesis awal yang diajukan penelitian. Diketahui juga nilai signifikan hitung pada variabel Transparansi sebesar 0,004 dan nilai signifikansi Transparansi 0,05 . Ketika disandingkan nilai signifikansinya diperoleh jika nilai signifikansinya kurang dari 0,05 yang menjelaskan Transparansi memiliki keterkaitan yang signifikan terhadap Kinerja Anggaran berkonsep $V$ alue for Money.

2. Pengaruh Akuntabilitas Terhadap Kinerja Anggaran

Besaran nilai thitung Akuntabilitas senilai 2,680 dan nilai ttabel senilai 1,986 diperoleh bahwa nilai thitung $>$ ttabel yang menjelaskan diterimanya hipotesis awal yang diajukan penelitian. Diketahui juga nilai signifikansi hitung pada variabel Akuntabilitas sebesar 0,009 dan nilai signifikansi Akuntabilitas 0,05. Ketika disandingkan nilai signifikansinya diperoleh jika nilai signifikansinya kurang dari 0,05 yang menjelaskan Akuntabilitas memiliki keterkaitan yang signifikan terhadap Kinerja Anggaran berkonsep $V$ alue for Money.

3. Pengaruh Pengawasan Terhadap Kinerja Anggaran

Besaran nilai thitung Pengawasan senilai 2,419 dan nilai ttabel senilai 1,986 diperoleh bahwa nilai thitung $>$ ttabel yang menjelaskan diterimanya hipotesis awal yang diajukan 
penelitian. Diketahui juga nilai signifikansi hitung pada variabel Pengawasan sebesar 0,00 dan nilai signifikansi Pengawasan 0,05. Ketika disandingkan nilai signifikansinya diperoleh jika nilai signifikansinya kurang dari 0,05 yang menjelaskan Pengawasan memiliki keterkaitan yang signifikan terhadap Kinerja Anggaran berkonsep Value for Money.

4. Pengaruh Transparansi, Akuntabilitas dan Pengawasan Terhadap Kinerja Anggaran

Berdasarkan pengolahan data, diperoleh hasil sebagai berikut.

\section{Tabel 2}

Hasil Uji Signifikansi Simultan (Uji F Anova)

\begin{tabular}{lrrrrr}
\hline Model & Sum of Squares & f & Mean Square & F & Sig. \\
\hline Regression & 542,204 & & 180,735 & 21,963 &, $000^{\mathrm{b}}$ \\
\hline Residual & 674,785 & 2 & 8,229 & & \\
\hline Total & 1216,988 & 5 & & & \\
\hline
\end{tabular}

a. Dependent Variable: Kinerja Anggaran

b. Predictors: (Constant), Pengawasan, Transparansi, Akuntabilitas

Output SPSS IBM, data di olah (2021)

Berdasarkan Tabel 2 diatas diperoleh bahwa besaran nilai Fhitung senilai 21,963 dengan signifikansi 0,000 dan nilai Ftabel senilai 2,71 yang menjelaskan adanya indikasi temuan berupa nilai Fbitung $>$ Ftabel menunjukkan secara bersamaan variabel independen pada penelitian ini ialah Transparansi (X1), Akuntabilitas (X2) dan Pengawasam (X3) memiliki keterkaitan terhadap variabel dependen berupa Kinerja Anggaran yang berkonsep Value for Money (Y).

\section{Tabel 3}

Hasil Uji Koefisien Determinasi (Uji $\mathbf{R}^{2)}$

\begin{tabular}{|c|c|c|c|c|}
\hline Model & $\mathrm{R}$ & R Square & Adjusted R Square & $\begin{array}{l}\text { Std. Error of the } \\
\text { Estimate }\end{array}$ \\
\hline 1 & $667^{a}$ & ,446 & 425 & 2,869 \\
\hline
\end{tabular}

a. Predictors : (Constnat), Pengawasan, Transparansi, Akuntabilitas

b. Dependent Variabel : Kinerja Anggaran

Output SPSS IBM, data di olah (2021)

Berdasarkan Tabel 3 diatas didapatkan bahwa besaran kontribusi keterkaitan yang disokong oleh variabel independen terhadap variabel dependen dengan mempertimbangkan besaran nila $\mathrm{R}$ Square. Diperoleh bahwa nilai Adjusted R Square 0,425 atau 42,5\%, yang menjelaskan bahwa Transparansi (X1), Akuntabilitas (X2) dan Pengawasan (X3) bersamaan memberikan kontribusi sebesar 42,5\% terhadap Kinerja Anggaran berkonsep Value for Money (Y), dan sisanya sebesar 57,5\% (100\% - Adjusted R Square) merupakan besar kontribusi faktor lain yang tidak diteliti di penelitain ini misalnya supremasi hokum, partisipasi masyarakat, dan berkeadilan.

\section{PEMBAHASAN}

\section{Analisis Pengaruh Transparansi terhadap Kinerja Anggaran}

Berdasarkan hasil pengujian hipotesis diperoleh bahwa nilai thitung variabel Transparansi sebesar 2,922, nilai t tabel sebesar 1,989, nilai signifikannya 0,004, dan hasil 
koefisien regresi positif yang artinya menjelaskan nilai thitung $>\mathrm{t}$ tabel dan nilai signifikan tidak lebih dari 0,05 menunjukkan jika hipotesis yang diteliti pada $H_{0}$ tidak diterima dan $H_{a}$ diterima. Maka diperoleh jika terdapat keterkaitan yang positif signifikan antara Transparansi dengan Kinerja Anggaran berkonsep V alue for Money.

Transparansi merupakan salah satu pilar dalam good govervance dan oleh karenanya pentingnya dibuatnya regulasi yang mengatur mengenai penyusunan anggaran oleh pemerintah agar tercapainya kesuksesan dalam implementasi penggunaan anggaran dengan mempertimbangkan pada tercapainya aspek kemudahan memperoleh informasi oleh pihak yang berkepentingan dan masyarakat. Penerbitan regulasi oleh pemerintah diatur di dalam undang-undang yang mengatur perihal keterbukaan mengakses informasi Hal ini sejalan dengan semangat pasal 9 UU keterbukaan informasi publik(Indonesia, 2008) yang mengamanatkan agar Badan Publik dapat menyediakan dan mengumumkan informasi publik secara berkala.

Namun ditemukannya hasil penelitian ynag sejenis tetapi berbeda yang didapat dari penelitian yang dilakukan oleh (Laoli, 2019) dan (Siregar, 2011) yang menemukan bahwa Transparansi tidak berpengaruh signifikan dan memiliki pengaruh negatif. Menunjukkan bahwa Transparansi tidak terlalu berpengaruh atas Kinerja Anggaran dengan konsep V alue For Money. Hal ini dapat dimungkinkan apabila Transparansi yang direncanakan oleh instansi pemerintah membebankan pegawai dalam proses pelaksanaannya sehingga hasil yang diperoleh atas Kinerja Anggaran tersebut tidak berjalan secara maksimal. Sehinga dapat dijelaskan jika adanya indikasi bahwa Transparansi berpengaruh terhadap Kinerja Anggaran Berkonsep Value For Money pada Organisasi Perangkat Daerah di Provinsi Sumatera Selatan. Semakin mudah publik untuk mengakses anggaran pemerintah maka meningkatkan Kinerja Anggaran Organisasi Perangkat Daerah, hal ini sejalan dengan penelitian (Akhmadi, 2014) dan (Suci muti'ah, 2019).

\section{Analisis Pengaruh Akuntabilitas terhadap Kinerja Anggaran}

Berdasarkan hasil pengujian hipotesis diperoleh bahwa nilai thitung variabel Akuntabilitas sebesar 2,680, nilai t tabel sebesar 1,989, nilai signifikannya sebesar 0,009, dan hasil koefisien regresi positif yang artinya menjelaskan nilai thitung $>\mathrm{t}$ tabel dan nilai signifikan kurang dari 0,05 menunjukkan jika hipotesis yang diteliti pada $H_{0}$ tidak diterima dan $H_{a}$ diterima. Maka diperoleh jika terdapat keterkaitan yang positif signifikan antara Akuntabilitas pada Kinerja Anggaran berkonsep V alue For Money.

Akuntabilitas adalah suatu bentuk pertanggungjawaban yang dilakukan oleh seseorang yang didelegasikan kepercayaan untuk menjalankan tugas dan tanggungjawabnya yang berkaitan hak dan wewenang dapat berupa laporan keuangan yang disajikan dan dapat dipertanggungjawabkan oleh pihak yang diberikan wewenang tersebut. Papenfu \& Schaefer (Papenfuß \& Schaefer, 2010) dan Keay (Keay, 2017) dalam teori Stewardship theory, Akuntabilitas yang bermutu akan meng informasikan bahwa telah dilaksanakannya pengelolaan keuangan negara dengan akuntabel serta dapat dipertanggung jawabkan. Dalam pelaksanaanya akuntabilitas suatu organisasi perangkat daerah dipengaruhi oleh peraturan dan perundang-undangan yang merupakan aturan guna membantu pemerintah dalam pelaksanaan kegiatan yang berpijak pada kepentingan publik. Sesuai dengan tujuan bernegara yaitu memberikan pelayanan kepada masyarakat secara optimal.

Hasil pengujian ini selaras dengan beberapa penelitian-penelitian sebelumnya (Laoli, 2019) dan (Suharyono, 2019) yang menyatakan akuntabilitas berdampak signifikan atas kinerja anggaran.. Apabila penerapan akuntabilitas semakin meningkat, maka semakin tinggi 
pula kinerja anggaran. Guna mewujudkan kinerja anggaran yang baik memerlukan pertanggungjawaban anggaran supaya menghasilkan laporan keuangan yang diharapkan.

\section{Analisis Pengaruh Pengawasan terhadap Kinerja Anggaran}

Hasil pengujian hipotesis diperoleh bahwa nilai thitung variabel Pengawasan sebesar 2,419, nilai t tabel sebesar 1,989, nilai signifikannya sebesar 0,018, dan hasil koefisien regresi positif yang artinya menjelaskan nilai thitung $>\mathrm{t}$ tabel dan nilai signifikan kurang dari 0,05 menunjukkan jika hipotesis yang diteliti pada $H_{0}$ tidak diterima dan $H_{a}$ diterima.Maka diperoleh jika terdapat keterkaitan yang positif signifikan antara Pengawasan dengan Kinerja Anggaran berkonsep V alue for Money.

Pengawasan yang dilakukan baik secara langsung ataupun tidak langsung sebagai upaya menekan terjadinya ketidak patuhan atas kemungkinan terjadinya penyimpangan dalam pelaksanaan kegiatan. Hal ini sebagai tindakan preventif agar kegiatan berjalan efektif dan efesien serta ekonomis. Organisasi perangkat daerah adalah pihak yang secara langsung bertanggung jawab atas terselenggaranya kegiatan sesuai rencana. Bentuk pengawasan langsung biasanya dilakukan oleh perseorangan atau pribadi melalui pengamatan, menelaah, mengidentifikasi, memeriksa secara mandiri suatu pekerjaan dengan cara inpeksi inspeksi. Sedangkan pengawasan tidak langsung dilakukan melalui monitoring.Salah satu cara pengawasan yang dilakukan eksternal dan merupakan pengawasan tidak langsung seperti terungkap pada pemeriksaan Badan Pemeriksa keuangan Negara dimana terdapat 416 kasus yang mengandung 614 permasalahan, meliputi 538 (87,62\%) persoalan ketidakpatuhan terhadap peraturan serta perundang-undangan sebesar Rp176,79 miliar serta $76(12,37 \%)$ permasalahan ketidakhematan, ketidakefisienan dan ketidakefektifan dan atas temuan ini telah disetorkan kembali ke Negara(Badan Pemeriksa Keuangan RI, 2019). Adanya pengawasan yang dilakukan akan berpengaruh terhadap kinerja anggaran yang lebih baik begitupun sebaliknya kurangnya pengawasan akan berdampak atas keuangan negara.

Hasil penelitian ini sejalan dengan penelitian terdahulu yang dilakukan oleh (Rigian \& Sari, 2019) dan (Novatiani, Kusumah, \& Vabiani, 2019) yang menyatakan bahwa Pengawasan berpengaruh signifikan positif terhadap Kinerja Anggaran dengan konsep Value For Money artinya Pengawasan adalah salah satu unsur dalam mencapai Kinerja Anggaran yang baik.

\section{Analisis Pengaruh Transparansi, Akuntabilitas, dan Pengawasan terhadap Kinerja Anggaran}

Hasil pengujian signifikansi simultan (Uji F) pada penelitian ini menguaraikan jika Transparansi, Akuntabilitas, dan Pengawasan berpengaruh secara positif dan signifikan terhadap Kinerja Anggaran dengan konsep Value For Money. Hasil perhitungan dalam penelitian ini menunjukkan bahwa nilai Fhitung sebesar 21,963 lebih besar dari nilal Ftabel sebesar 2,71 dan nilai signifikan sebesar 0,000 lebih kecil dari 0,05. Dengan demikian, dapat disimpulkan bahwa terdapat pengaruh yang positif dan signifikan pada variabel Transparansi, Akuntabilitas, dan Pengawasan terhadap Kinerja Anggaran Berkonsep Value For Money.

Dari hasil analisis kekuatan hubungan secara simultan atau analisis untuk mengetahui seberapa besarnya variabel bebas (independen) menjelaskan variabel bebas (independen) menjelaskan variabel terikat (dependen), maka diketahui bahwa koefisien determinasi $\mathrm{R}$ Square sebesar 0,446 atau 44,6\%. Sedangkan sisanya sebesar 55,4\% diperoleh oleh variabel lain yang tidak diamati di dalam penelitian ini. Nilai 44,6\% menjelaskan bahwa variabel 
Kinerja Anggaran Berkonsep Value For Money dipengaruhi oleh Transparansi, Akuntabilitas, dan Pengawasan sebesar 44,6\% pada Organisasi Perangkat Daerah Provinsi Sumatera Selatan. Dari perhitungan ini terlihat bahwa untuk meningkatkan transparansi, akuntabilitas dan pengawasan diperlukan faktor lain seperti ketaatan atas hukum dan pengawasan masyarakat sehingga kinerja anggaran dapat meningkat.

\section{KESIMPULAN}

Berdasarkan hasil pengujian yang dilakukan dapat disimpulkan bahwa baik secara parsial maupun simultan variabel Transparansi (X1), Akuntabilitas (X2) dan Pengawasan (X3) memberikan pengaruh terhadap kinerja anggaran Pada Organisasi Perangkat Daerah (OPD) Provinsi Sumatera Selatan, dimana sebesar 44,6\% terhadap Kinerja Anggaran Berkonsep Value For Money (Y), sedangkan sisanya sebanyak 42,4 \% (100\% - Adjusted R Square) merupakan besarnya kuantitas pengaruh lain yang diberikan oleh faktor lain tidak diteliti pada penelitian ini seperti supremasi hukum dan partisipasi masyarakat dan berkeadilan.

\section{REFERENSI}

Akhmadi, A. (2014). Pengaruh Akuntabilitas dan Transparansi terhadap Efektivitas Pelaksanaan Anggaran Pada Satuan Kerja Perangkat Daerah Pemerintah Kabupaten Batang Hari Akhmadi. Jurnal Manajemen Dan Kewirausahaan, 5(3), 1-16.

Badan Pemeriksa Keuangan RI. (2019). IHPD PROVINSI SUMATERA SELATAN. jakarta.

Brantas. (2009). Dasar-Dasar Manajemen. Bandung: Alfabeta.

Candrakusuma, D. A., \& Jatmiko, B. (2017). Dampak Komitmen Organisasi,Sistem Pengendalian Intern Pemerintah,Akuntabilitas Publik,Partisipasi Anggaran dan kejelasan Sasaran Anggaran Terhadap Kinerja Manajerial. Jurnal Bisnis Dan Ekonomi, 24(1), 87-93. https://doi.org/10.1017/CBO9781107415324.004

Indira, B. (2010). Akuntansi Sektor Publik. Jakarta: Erlangga.

Indonesia, P. R. UU No.14 Tahun 2008 (2008).

Keay, A. (2017). Stewardship theory: is board accountability necessary. International Journal of Law and Management, 59(Unit 06), 1292-1314. Retrieved from https://doi.org/10.1108/IJLMA-11-2016-0118

Khalikussabir. (2017). Analisis Kinerja Keuangan Berdasarkan Value For Money (Studi Kasus Pada Dinas PU Pengairan, PU Binamarga \& PU Cipta KaryaKabupaten Probolinggo). E-Jumal Riset Manajemen, 1(1), 1-22.

Laksana, A. P., \& Handayani, B. D. (2014). Pengaruh Kejelasan Sasaran Anggarn, Pengawasan Fungsional,dan Pelaporan Kinerja Terhadap Akuntabilitas Publik Di Kabupaten Batan. Accounting Analysis Journal, 3(4), 457-465.

Laoli, V. (2019). Pengaruh Akuntabilitas dan Transparansi terhadap Kinerja Anggaran Berkonsep Value of Money pada Pemerintah Kabupaten Nias. Owner, 3(1), 91. https://doi.org/10.33395/owner.v3i1.108

Mahmudi. (2015). Manajemen Kinerja Sektor Pulbik. Yogyakarta: UPP STIM YKPN. 
I-FINANCE: a Research Journal on Islamic Finance Vol.07 No. 01 Juni 2021 http//jurnal.radenfatah.ac.id/index.php/i-finance .Analisis Kinerja Anggaran

Mardiasmo. (2019). Akuntansi Sektor Publik. Jogyakarta: CV.Andi Offset.

Novatiani, A., Kusumah, R. W. R., \& Vabiani, D. P. (2019). Pengaruh Transparansi dan Akuntabilitas Terhadap Kinerja Instansi Pemerintah. Ilmu Manajemen Dan Bisnis, 10(1), 51-61.

Papenfuß, U., \& Schaefer, C. (2010). Improving public accountability by aligning reporting to organizational changes in public service provision - an empirical Internet study of all Austrian, German and Swiss towns and states from an agency-theory perspective. International Review of Administrative Sciences, 76(3), 555-576. https://doi.org/10.1177/0020852310372451

Purnomo, B. S., \& Putri, C. (2018). Akuntabilitas, Transparansi, Pengawasan dan Kinerja Anggaran Berkonsep Value For Money. Jumal Riset Akuntansi \& Kenangan, 6(3), 467480. https://doi.org/10.17509/jrak.v6i3.14886

Purwiyanti, D. (2017). Analisis Kinerja Berbasis Konsep Value for Money pada Kegiatan Fisik Pekerjaan Irigasi Donggala Kodi( studi di Dinas Pekerjaan Umum Kota Palu). Katalogis, 5(3), 190-200.

Reynowijoyo, M. (2013). Akuntansi Sektor Publik. Jakarta: Mitra Wacana Media.

Rigian, D., \& Sari, R. P. (2019). Pengaruh akuntabilitas, transparansi, dan partisipasi Terhadap kinerja anggaran berbasis value for money. Journal of Business and Information Systems (e-ISSN: 2685-2543), 1(1), 38-47. https://doi.org/10.36067/jbis.v1i1.11

Siregar, L. (2011). Pengaruh Akuntabilitas Publik,Transparansi Publik dan pengawasan Terhadap Pengelolaan APBD Dengan Standar Akuntansi Pemerintah Sebagai Variabel Moderator Pada Pemerintah Kota Pematang Siantar. Http://Repository.Usu.Ac.Id/Handle/123456789/29358, (x), 84-90.

Sofyani, U. I. dan H. (2016). Akuntansi Sektor Publik. Malang: Aditya Media.

Suci muti'ah. (2019). Pengaruh Akuntabilitas,tranparansi, dan pengawasan thd kinerja dengan efektivitas angggaran sbg variabel intervening pada opd kabupaten magetan dan ngawi. Universitas Jember, jember.

Sugiono. (2012). satatistik untuk penelitian. Jogyakarta: BPFE.

Suharyono, S. (2019). The Effect Of Accountability, Transparency, And Supervision On Budget Performance By Using The Concept Of Value For Money In Regional Business Enterprises (Bumd) Of Riau Province. International Journal of Public Finance, 4(2), 236-249. https://doi.org/10.30927/ijpf.584834

Wijayanti, M., \& Babulu, N. L. (2019). Determinan Efektivitas Belanja Daerah dan Dampaknya Pada Pertumbuhan Ekonomi. Jurnal Ekonomi Pembangunan, 53(9), 1689_ 1699. https://doi.org/10.1017/CBO9781107415324.004 